\title{
Serotonin transporter overexpression is responsible for pulmonary artery smooth muscle hyperplasia in primary pulmonary hypertension
}

\author{
Saadia Eddahibi, ${ }^{1}$ Marc Humbert, ${ }^{2}$ Elie Fadel, ${ }^{3}$ Bernadette Raffestin, ${ }^{4}$ Michèle Darmon, ${ }^{5}$ \\ Frédérique Capron, ${ }^{2}$ Gerald Simonneau, ${ }^{2}$ Philippe Dartevelle, ${ }^{3}$ Michel Hamon, ${ }^{5}$ \\ and Serge Adnot ${ }^{1}$
}

${ }^{1}$ Institut National de la Santé et de la Recherche Médicale (INSERM) U492 and

Département de Physiologie, Hôpital Henri Mondor, AP-HP, Créteil, France

${ }^{2}$ UPRES EA2705, Service de Pneumologie, Hôpital Antoine Béclère, AP-HP, Clamart, France

${ }^{3}$ UPRES EA2705, Service de Chirurgie Thoracique, Vasculaire et de Transplantation Cardiopulmonaire,

Hôpital Marie Lannelongue, Le Plessis Robinson, France

${ }^{4}$ Département de Physiologie, Université René Descartes, Hôpital Ambroise Paré, Boulogne, France

${ }^{5}$ INSERM U288, NeuroPsychoPharmacologie Moléculaire, Cellulaire et Fonctionnelle,

Faculté de Médecine Pitié-Salpêtrière, Paris, France

Address correspondence to: Serge Adnot, INSERM U492, Département de Physiologie, Faculté de Médecine de Créteil, 94010 Créteil, France. Phone: 33-1-49-81-36-93; Fax: 33-1-48-98-17-77; E-mail: serge.adnot@hmn.ap-hop-paris.fr.

Received for publication March 26, 2001, and accepted in revised form August 21, 2001.

\begin{abstract}
Hyperplasia of pulmonary artery smooth muscle cells (PA-SMCs) is a hallmark pathological feature of primary pulmonary hypertension (PPH). Here we found that PA-SMCs from patients with PPH grow faster than PA-SMCs from controls when stimulated by serotonin or serum and that these effects are due to increased expression of the serotonin transporter (5-HTT), which mediates internalization of indoleamine. In the presence of 5-HTT inhibitors, the growth stimulatory effects of serum and serotonin were markedly reduced and the difference between growth of PA-SMCs from patients and controls was no longer observed. As compared with controls, the expression of 5-HTT was increased in cultured PA-SMCs as well as in platelets and lungs from patients with PPH where it predominated in the media of thickened pulmonary arteries and in onion-bulb lesions. The L-allelic variant of the 5HTT gene promoter, which is associated with 5-HTT overexpression and increased PA-SMC growth, was present in homozygous form in $65 \%$ of patients but in only $27 \%$ of controls. We conclude that 5-HTT activity plays a key role in the pathogenesis of PA-SMC proliferation in PPH and that a $5 H T T$ polymorphism confers susceptibility to $\mathrm{PPH}$.
\end{abstract}

J. Clin. Invest. 108:1141-1150 (2001). DOI:10.1172/JCI200112805.

\section{Introduction}

Pulmonary hypertension $(\mathrm{PH})$ is characterized by an increase in pulmonary vascular resistance that impedes ejection of blood by the right ventricle and leads to right ventricular failure. Primary $\mathrm{PH}(\mathrm{PPH})$ is the clinical term used to describe a rare and fatal condition for which no underlying cause can be found (1). Its pathogenesis remains largely unknown, although recent reports of familial PPH associated with BMPR2 gene mutations suggest a role for genetic predisposition $(2,3)$. Histologically, the remodeled pulmonary arteries show various degrees of medial hypertrophy and intimal thickening that, ultimately, lead to obliteration of the vessels. Hyperplasia of pulmonary artery smooth muscle cells (PA-SMCs) is the main component of these changes (4). Its origin, however, remains unknown.

Investigations on serotonin, 5-hydroxytryptamine (5-HT), and its transporter (5-HTT) in patients with
$\mathrm{PPH}$ are of special interest because an increased risk of PPH has been reported in patients who used appetite suppressants interfering with 5-HT (5). In previous studies, we found that 5-HT promoted the development of hypoxic PH by stimulating PA-SMC growth (6). As shown in bovine and rat PA-SMCs, the mitogenic and comitogenic effects of 5-HT require internalization of indoleamine by a high-affinity and selective transporter $(7,8)$. Exposure of PA-SMCs to hypoxia results in a rapid increase in 5-HTT expression and activity, together with a marked enhancement in the growth-promoting effect of 5-HT (7). Increased 5-HTT gene expression also occurs in remodeled pulmonary arteries from animals developing $\mathrm{PH}$ related to chronic hypoxia exposure (7). Moreover, mice with targeted disruption of the 5-HTT gene develop less severe hypoxic $\mathrm{PH}$ than wild-type controls (9), which is direct evidence that 5-HTT plays a key role in pulmonary vessel remodeling. 
5-HTT is encoded by a single gene on chromosome $17 \mathrm{q} 11.2$ and is expressed in various cell types including neurons, blood platelets, and pulmonary artery endothelial and SMCs $(10,11)$. The level of 5-HTT expression appears to be much greater in human lung than in human brain (11), suggesting that altered 5-HTT expression may have direct consequences on PA-SMC function. Recently, a variant in the upstream promoter region of the 5-HTT gene was described. This insertion/deletion polymorphism with long (L) and short (S) forms affects 5-HTT expression and function, with the $\mathrm{L}$ allele driving a twofold to threefold higher rate of 5-HTT gene transcription than the $\mathrm{S}$ allele (12).

The aim of the present study was to examine the role of 5-HTT in mediating PA-SMC growth in PPH. We first quantified 5-HTT in platelets and lungs from patients with $\mathrm{PPH}$ and controls. We then examined the growth of cultured PA-SMCs isolated from patients and controls and its relation to 5-HTT activity and expression. Finally, we investigated whether 5-HTT gene polymorphism influenced the growth of PA-SMCs and/or was associated with PPH.

\section{Methods}

Determination of 5-HTT genotype and measurement of platelet 5-HTT activity

Population under study. The population under study comprised 89 patients suffering from severe primary pulmonary hypertension $(\mathrm{PPH})$, including men and women aged (mean \pm SD) $46 \pm 12$ years (range 18-69) and 84 normal subjects, men and women aged $46 \pm 11$ years. All patients underwent right-sided cardiac catheterization within 18 months before the study. Patients with concomitant HIV infection, associated liver disease, connective tissue disease, or airway or interstitial pulmonary disease were not included in the study. The mean pulmonary artery pressure (Pap) in this group of patients was $62 \pm 12 \mathrm{mmHg}$ (range, 39-91 $\mathrm{mmHg}$ ). All the controls were healthy and participated in a variety of recreational physical activities. None were known to have an acute or chronic illness, except for mild systemic hypertension treated with a beta-blocking drug or oral vasodilator in six controls. Before inclusion in the study, all patients and controls signed an informed consent document, and the study was approved by our institutional review board.

All subjects underwent blood sampling for 5-HTT genotype determination. Platelet $\left[{ }^{3} \mathrm{H}\right] 5-\mathrm{HT}$ uptake and 5-HTT-binding activity were investigated in a subgroup of 14 controls and 13 patients whose clinical and hemodynamic characteristics were similar to those of the overall population of study patients.

Measurement of platelet $\left[{ }^{3} \mathrm{H}\right] 5$-HT uptake and $\left[{ }^{3} \mathrm{H}\right]$ citalopram binding. Blood samples obtained from a peripheral forearm vein in the patients and controls were centrifuged at $600 \mathrm{~g}$ for 10 minutes in $13 \mathrm{mM}$ sodium citrate to obtain platelet-rich plasma (PRP). The pro- tocol used to measure platelet $\left[{ }^{3} \mathrm{H}\right] 5-\mathrm{HT}$ uptake was adapted from Prina et al. (13). Briefly, assays were performed by incubating $100 \mu \mathrm{l}$ of PRP $\left(10^{7}\right.$ platelets $)$ with $0.2 \mu \mathrm{M} 5$-hydroxy[G- $\left.{ }^{3} \mathrm{H}\right]$ tryptamine creatinine sulfate $\left(15-16 \mathrm{Ci} / \mathrm{mmol}\left[{ }^{3} \mathrm{H}\right] 5-\mathrm{HT}\right.$; Amersham International, Buckinghamshire, United Kingdom). Under these conditions, $\left[{ }^{3} \mathrm{H}\right] 5$-HT uptake by platelets was linear for at least 5 minutes. Incubation proceeded for 1 minute at $37^{\circ} \mathrm{C}$ with or without the specific 5 -HTT inhibitor fluoxetine $\left(10^{-9}\right.$ to $\left.10^{-5} \mathrm{M}\right)$. Then, the reaction was stopped by adding $2 \mathrm{ml}$ of ice-cold $0.9 \%$ (wt $/ \mathrm{vol}$ ) $\mathrm{NaCl}$ containing $0.4 \%$ (wt/vol) EDTA, and the samples were centrifuged at $3,600 \mathrm{~g}$ for 10 minutes. The platelets in the pellets were washed three times using $2 \mathrm{ml}$ of the $\mathrm{NaCl}$-EDTA mixture solution, then centrifuged as above. The platelet-free supernatant was discarded, and the platelet pellet was lysed by addition of $1 \mathrm{ml}$ of $0.1 \mathrm{~N} \mathrm{NaOH}$. Lysate radioactivity was counted using liquid scintillation spectrometry. Specific $\left[{ }^{3} \mathrm{H}\right] 5-\mathrm{HT}$ uptake calculated as the difference between total uptake and uptake in the presence of fluoxetine $\left(10^{-5} \mathrm{M}\right)$ is expressed as femtomoles of $\left[{ }^{3} \mathrm{H}\right] 5-\mathrm{HT}$ taken up per $10^{7}$ platelets.

$\left[{ }^{3} \mathrm{H}\right]$ citalopram binding was measured on platelets prepared by PRP centrifugation as described above. Platelet pellets were resuspended in $1 \mathrm{ml}$ of a buffer containing, in millimoles per liter, 50 Tris- $\mathrm{HCl}, 2$ $\mathrm{MgCl}_{2}, 120 \mathrm{NaCl}, \mathrm{KCl}$ 5, 0.5 ascorbic acid, $\mathrm{pH} 7.4$ (binding buffer), plus $1 \mathrm{nM}$ of $\left[{ }^{3} \mathrm{H}\right]$ citalopram. Samples for measurement of nonspecific binding were supplemented with fluoxetine $\left(10^{-5} \mathrm{M}\right)$ as the displacing agent. After a 60 -minute incubation at $37^{\circ} \mathrm{C}$, the reaction was stopped by addition of $10 \mathrm{ml}$ of ice-cold buffer. Rapid filtration through Whatman glass fiber filters (grade GF/C; Sigma-Aldrich, SaintQuentin Fallavier, France) presoaked with binding buffer was the next step. The filters were washed three times with $10 \mathrm{ml}$ of ice-cold binding buffer, then dried; entrapped radioactivity was counted using liquid scintillation spectrometry. Specific $\left[{ }^{3} \mathrm{H}\right]$ citalopram binding was calculated by subtracting the nonspecific binding in the presence of fluoxetine from the total binding and is expressed as femtomoles $\left[{ }^{3} \mathrm{H}\right]$ citalopram bound per $10^{8}$ platelets.

Genotyping. Genomic DNA was extracted from whole blood and from human pulmonary artery-SMC's (HPA-SMCs) using Mini Genomic Kit (Eurobio, Les Ulis, France). The 5-HTT gene promoter region was amplified by PCR with the oligonucleotide primers $5^{\prime}$ GGCGTTGCCGCTCTGAATGC- $3^{\prime}$ and $5^{\prime}$-GAGGGACTGAGCTGGACAACCAC-3' (8). Amplification was performed with 50 ng of genomic DNA, 10 pmol of each primer, $20 \mathrm{mM} \mathrm{KCl}, 10 \mathrm{mM}$ Tris- $\mathrm{HCl}$ ( $\mathrm{pH} 8.8), 16 \mathrm{mM}$ $\left(\mathrm{NH}_{4}\right)_{2} \mathrm{SO}_{4}, 0.01 \%$ (vol/vol) Tween-20, $200 \mu \mathrm{M}$ of each deoxynucleotide, and $1 \mathrm{U}$ of Eurobiotaq polymerase in a total volume of $25 \mu \mathrm{l}$. Cycling conditions were preceded by a denaturation step at $95^{\circ} \mathrm{C}$ for 10 minutes, followed by 35 cycles of denaturation at $95^{\circ} \mathrm{C}$ for 1 minute, annealing at $60^{\circ} \mathrm{C}$ for 1 minute and synthesis 
at $72^{\circ} \mathrm{C}$ for 1 minute. Amplification products were separated by electrophoresis in $2 \%$ agarose gel stained with ethidium bromide. The 484-bp and 528-bp fragments corresponded to the biallelic $\mathrm{S}$ and $\mathrm{L}$ polymorphisms, respectively.

\section{Studies performed on lungs and} SMCs from pulmonary arteries

Population under study. Studies were performed on lung specimens obtained during lung transplantation in eight patients with PPH and during lobectomy or pneumonectomy for localized lung cancer tumor in 21 controls. Three patients with $\mathrm{PPH}$ were receiving prostacyclin therapy at the time of transplantation. In the lung specimens from controls, pulmonary arteries were studied at a distance from tumor areas. Mean age (mean \pm SD) was $47 \pm 11$ years for the patients with $\mathrm{PPH}$ and $52 \pm 13$ years for the controls. The mean Pap in the group with PPH was $62 \pm 13 \mathrm{mmHg}$ (range, $53-78 \mathrm{mmHg}$ ). Preoperative transthoracic echocardiography was performed in the controls to rule out $\mathrm{PH}$. Quantitative determination of 5-HTT $m R N A$. Tissue total RNA was extracted from lung tissues according to the method of Chomczynski and Sacchi (14) and electrophoresed in $1 \%$ agarose gel stained with ethidium bromide. Quantification was performed with reference to a scale of total RNAs prepared on a cesium chloride gradient and was estimated by OD measurement at 260 $\mathrm{nm}$. This method is based on competitive PCR (15) in which RNAs are reverse transcribed, and the synthesized cDNAs are amplified in the presence of an internal standard consisting of the same target mRNA with deletion of about 100 bases (16). Total RNAs $(0.8 \mu \mathrm{g}$ per sample) and internal standard RNA (0.01-1 pg) were reverse transcribed $\left(45\right.$ minutes at $\left.48^{\circ} \mathrm{C}\right)$ and amplified using the access RT-PCR kit (Promega France, Charbonnieres, France) with the primers 5'TTACACAGCATTCATGCG (nucleotides 2008-1991 of the 5-HTT cDNA) and 5'-GGATCCCTGCTCACACTG (nucleotides 1541-1558) in the presence of $2.5 \mathrm{mM}$ $\mathrm{MgCl}_{2}$. Cycle amplifications were performed at $94^{\circ} \mathrm{C}$, $54^{\circ} \mathrm{C}$, and $72^{\circ} \mathrm{C}$ ( 1 minute each, 28 cycles). PCR products from the 5-HTT mRNA and the corresponding synthetic deleted RNA were of 484 and $400 \mathrm{bp}$, respectively. They were electrophoresed in $2 \%$ agarose gel stained with ethidium bromide, then quantified using a gel analyzer (Syngene Europe, Cambridge, United Kingdom). 5-HTT mRNA levels are reported as attomoles per microgram of total RNA.

Lung immunohistochemical analysis. Paraffin sections (5 $\mu \mathrm{m}$ thick) of lung specimens were mounted on Superfrost Plus slides (Fisher Scientific SA, Elancourt, France). For 5-HTT immunostaining, the slides were dewaxed in $100 \%$ toluene, and the sections were then rehydrated by immersion first in decreasing ethanol concentrations $(100 \%, 95 \%$, and $70 \%)$, then in distilled water. Endogenous peroxidase activity was blocked using $\mathrm{H}_{2} \mathrm{O}_{2}$ in methanol $(0.3 \% \mathrm{vol} / \mathrm{vol})$ for 10 minutes. After three washes with PBS, the sections were prein- cubated in PBS supplemented with 3\% (wt/vol) BSA for 30 minutes, then incubated overnight at $4^{\circ} \mathrm{C}$ with goat polyclonal anti-5-HTT Ab's (Santa Cruz Biotechnology Inc., Santa Cruz, California, USA) diluted 1:1,000 in PBS containing $0.02 \%$ BSA. The sections were exposed for 1 hour to biotin-labeled anti-goat secondary Ab's (Dako, Trappes, France) diluted 1:200 in the same buffer, then to streptavidin biotin horseradish peroxidase solution. Peroxidase staining was carried out using 3,3'-diaminobenzidine tetrahydrochloride dihydrate (DAB; Sigma Chemical Co., St. Louis, Missouri, USA) and hydrogen peroxide. Finally, the sections were stained with hematoxylin and eosin.

Culture of human PA-SMCs. PA-SMCs were cultured from explants. In brief, arteries (diameter: 5-10 $\mathrm{mm}$ ) were kept in DMEM at $4^{\circ} \mathrm{C}$ before their intimal cell layer and residual adventitial tissue were stripped off using forceps. The dissected media of the vessels was then cut into small pieces ( $3-5 \mathrm{~mm}$ ), which were transferred into cell-culture flasks. To allow the PA-SMCs to grow out, the vessel tissues were incubated in DMEM supplemented with $20 \%$ FCS, 2 mM L-glutamine, and antibiotics $(100 \mathrm{U} / \mathrm{ml}$ penicillin and $0.1 \mathrm{mg} / \mathrm{ml} \mathrm{strep-}$ tomycin). After 2 weeks of incubation, the PA-SMCs collected in the culture medium and the vessel tissues were transferred into new cell-culture flasks. Cultured PA-SMCs were used between passages 1 and 3. Explants from the same pulmonary artery were usually transferred several times.

Characterization of cultured PA-SMCs. To determine the phenotypic characteristics of cultured PA-SMCs from patients with PPH and controls, the cells from each culture were assessed for expression of the muscle-specific contractile and cytoskeletal proteins including smooth muscle cell $\alpha$-actin desmin, and vinculin using indirect single- or double-labeled immunofluorescence staining. Cells grown with $10 \%$ FCS on Lab-Tek chamber slides were fixed in absolute methanol at $-20^{\circ} \mathrm{C}$ for $10 \mathrm{~min}$ utes and processed for immunostaining by incubation for 60 minutes with anti-human smooth muscle cell $\alpha$-actin, desmin, or vinculin Ab's. The slides were then exposed for 1 hour to FITC-conjugated secondary Ab's (Dako) diluted 1:200. In control experiments, primary Ab's were replaced by nonimmune serum at the same dilutions. Immunofluorescence staining was examined under an epifluorescence microscope. Immunofluorescence analysis showed that all cultured PA-SMCs from patients with PPH and from controls showed a similar level of positive staining with Ab's against smooth muscle cell $\alpha$-actin, desmin, and vinculin.

Measurement of $\left[{ }^{3} \mathrm{H}\right] 5-\mathrm{HT}$ uptake. PA-SMCs in DMEM containing $15 \%$ FCS were seeded in 24-well plates at a density of $5 \times 10^{4}$ cells/well and allowed to proliferate for 72 hours. The medium was then removed and the cells subjected to growth arrest in medium containing only $0.2 \%$ FCS. After 24 hours of incubation, the cells were washed twice with PBS and exposed to $10 \mathrm{nmol} / 1$ $\left[{ }^{3} \mathrm{H}\right] 5-\mathrm{HT}$ in uptake buffer composed of $120 \mathrm{mmol} / \mathrm{l}$ $\mathrm{NaCl}, 5 \mathrm{mmol} / \mathrm{l} \mathrm{KCl}, 1.2 \mathrm{mmol} / 1 \mathrm{CaCl}_{2}, 1.2 \mathrm{mmol} / 1$ 

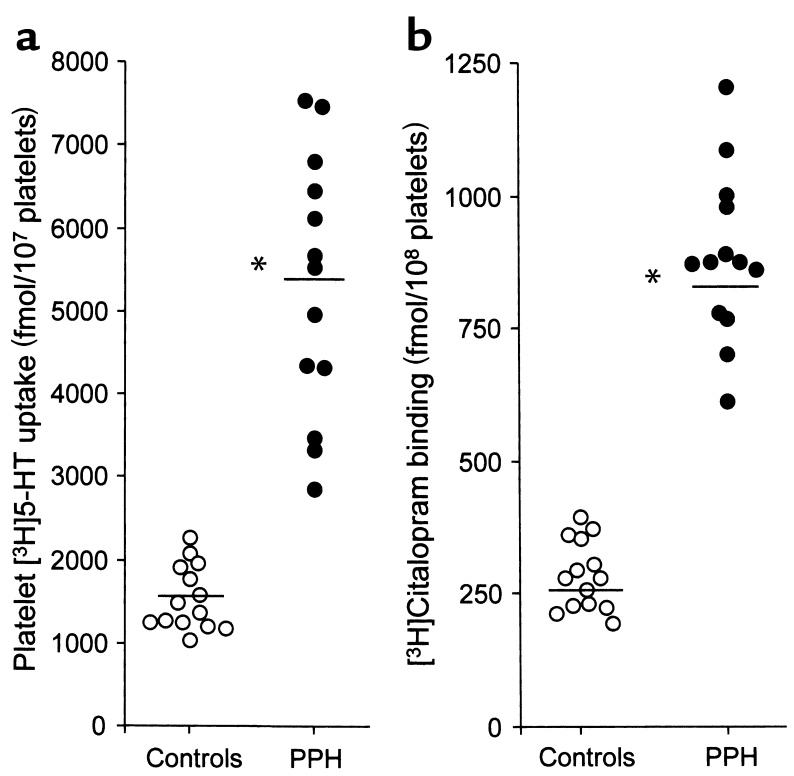

\section{Figure 1}

Individual platelet $\left[{ }^{3} \mathrm{H}\right] 5-\mathrm{HT}$ uptake $(\mathbf{a})$ and $\left[{ }^{3} \mathrm{H}\right]$ citalopram binding (b) in normal controls $(n=14)$ and in patients with $\mathrm{PPH}(n=13)$. Specific $\left[{ }^{3} \mathrm{H}\right] 5-\mathrm{HT}$ uptake and $\left[{ }^{3} \mathrm{H}\right]$ citalopram binding were determined as total values minus the values measured in the presence of fluoxetine $\left(10^{-5} \mathrm{M}\right)$. The mean of each group of values is indicated by horizontal bars. ${ }^{*} P<0.01$ as compared with corresponding values in controls. Platelet density was lower in patients with PPH than in controls ( $177 \pm 12$ vs. $238 \pm 16 \times 10^{3}$ platelets per microliter, respectively; $P<0.01)$.

$\mathrm{MgSO}_{4}, 5.6 \mathrm{mmol} / \mathrm{l}$ glucose, $4 \mathrm{mmol} / \mathrm{l}$ Tris- $\mathrm{HCl}, 6.25$ $\mathrm{mmol} / \mathrm{l} \mathrm{HEPES}$, and $0.5 \mathrm{mmol} / \mathrm{l}$ ascorbic acid, $\mathrm{pH} 7.4$. Under these conditions, $\left[{ }^{3} \mathrm{H}\right] 5$-HT uptake by PA-SMCs is linear for at least 15 minutes at $37^{\circ} \mathrm{C}$. Therefore, assays were performed for 10 minutes at $37^{\circ} \mathrm{C}$ with or without fluoxetine $\left(10^{-9}\right.$ to $\left.10^{-5} \mathrm{~mol} / \mathrm{l}\right)$. At the end of the incubation period, the medium was removed and the cells washed three times with ice-cold uptake buffer. The cells were lysed by addition of $0.5 \mathrm{ml}$ of 0.1 $\mathrm{N} \mathrm{NaOH}$, and lysate radioactivity was counted using liquid scintillation spectrometry.

5-HTT immunoblotting. PA-SMCs preserved in liquid nitrogen were used. After thawing at $0^{\circ} \mathrm{C}$, the cells were lysed in $0.1 \mathrm{mM}$ PBS containing antiproteases, and the homogenates were subjected to SDS-polyacrylamide gel electrophoresis. Proteins in the gel were transferred to a nitrocellulose membrane by electroblotting in a transblot BioRad transfer apparatus (BioRad Laboratories, Marnes la Coquette, France). The gels, Whatman filter paper, and nitrocellulose membrane were soaked in electroblotting buffer $(25 \mathrm{mM}$ Tris- $\mathrm{HCl}, 193 \mathrm{mM}$ glycine, $20 \%$ methanol, $\mathrm{pH} 8.0$ ) for 15 minutes before transferring. After protein transfer for 12 hours at $4^{\circ} \mathrm{C}$, the membrane was blocked with $1 \times$ TBST $(0.15 \mathrm{M} \mathrm{NaCl}, 10$ $\mathrm{mM}$ Tris- $\mathrm{HCl}, 0.05 \%$ Tween-20, 5\% BSA, pH 8.0) for 1 hour at room temperature. The 5-HTT protein was detected by incubating the membrane overnight at $4^{\circ} \mathrm{C}$ with goat polyclonal anti-5-HTT (Santa Cruz Biotech- nology Inc.) diluted 1:1,000. The membrane was washed three times in $1 \times$ TBST and stained with horseradish peroxidase-conjugated secondary $\mathrm{Ab}$ and enhanced chemiluminescence reagents (Amersham International).

5-HTT $m R N A$ levels. PA-SMCs were washed with PBS and lysed with guanidinium isothiocyanate (14). Total RNA extraction and competitive RT-PCR were then performed as described above.

Measurement of PA-SMC proliferation. PA-SMCs in DMEM supplemented with 15\% FCS were seeded in 24-well plates at a density of $5 \times 10^{4}$ cells/well and allowed to adhere. The cells were then subjected to 48 hours of growth arrest in medium containing only $0.2 \%$ FCS, then incubated in DMEM supplemented with $0.2 \%$ FCS, $0.6 \mathrm{mmol} / 1$ of ascorbic acid, $0.1 \mathrm{mmol} / 1$ of iproniazid (a monoamine oxidase inhibitor), 0.6 $\mu \mathrm{Ci} / \mathrm{ml}$ of $\left[{ }^{3} \mathrm{H}\right]$ thymidine, with or without 5 - $\mathrm{HT}\left(10^{-8}\right.$ to $\left.10^{-6} \mathrm{~mol} / \mathrm{l}\right)$, and/or PDGF-BB (10 $\mathrm{ng} / \mathrm{ml}$; Sigma Chemical Co.). The effect of 5-HT was also examined in the presence of fluoxetine $\left(10^{-5} \mathrm{~mol} / \mathrm{l}\right)$ or citalopram $\left(10^{-6} \mathrm{~mol} / \mathrm{l}\right)$, two specific 5 -HTT inhibitors, or GR127935 $\left(10^{-6} \mathrm{~mol} / \mathrm{l}\right)$, a $5-\mathrm{HT}_{1 \mathrm{~B} / 1 \mathrm{D}}$ receptor antagonist, added 20 minutes before the 5-HT. HPA-SMC proliferation was also assessed in response to FCS ( $2 \%$ and $5 \%$ ) and the mitogens EGF, FGFa, TGF- $\beta$, and PDGF$\mathrm{BB}$ at $10 \mathrm{ng} / \mathrm{ml}$ each. After incubation for 24 hours, the cells were washed twice with PBS, treated by ice-cold $10 \%$ trichloroacetic acid, and dissolved in $0.1 \mathrm{~N} \mathrm{NaOH}$ $(0.5 \mathrm{ml} /$ well $)$. The incorporated radioactivity was counted. $\left[{ }^{3} \mathrm{H}\right]$ thymidine incorporation into DNA is reported as counts per minute per well.

Statistical analyses. All data are reported as means plus or minus SEM. ANOVA was used for between-group comparisons. When ANOVA indicated significance, the groups were compared using a Mann-Whitney nonparametric test. P values less than 0.05 were considered statistically significant. Allele and genotype frequencies were compared using $\chi^{2}$ tests, and the test for HardyWeinberg equilibrium was performed in each group.

\section{Results}

5-HTT expression in platelets from patients with $P P H$. To characterize functional 5-HTT expression in patients with $\mathrm{PPH}$, we first assessed platelet 5-HTT transport and binding activities in 13 patients with $\mathrm{PPH}$ and 14 controls. Platelet $\left[{ }^{3} \mathrm{H}\right] 5-\mathrm{HT}$ uptake was markedly higher in patients with PPH than in controls. Also, an

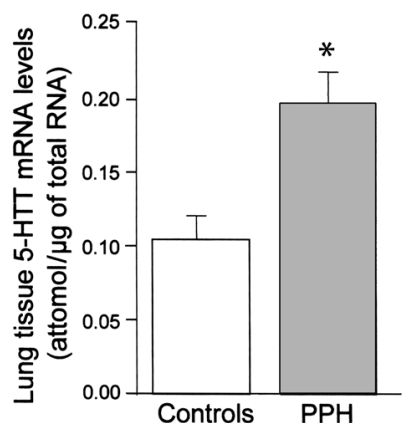

Figure 2

Levels of 5-HTT mRNA in lung tissues from patients with PPH $(n=6)$ and from controls $(n=5)$. Each bar is the mean \pm SEM. ${ }^{*} P<0.01$ as compared with the control values. 


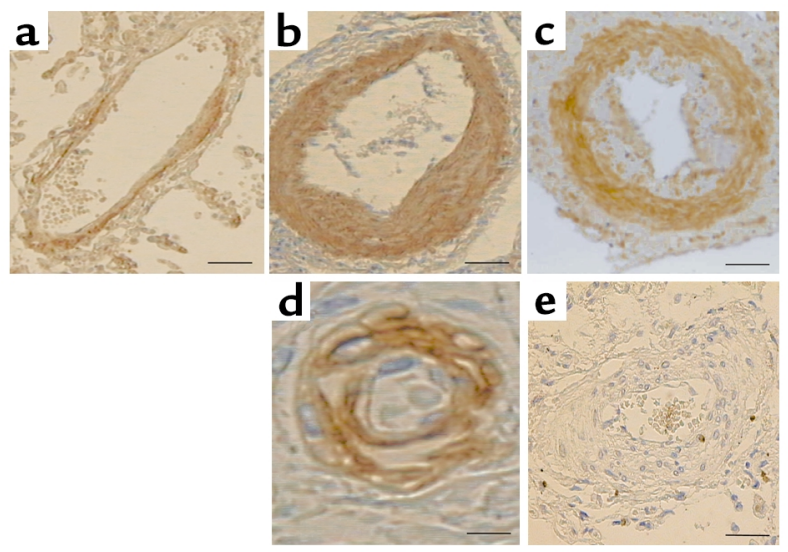

\section{Figure 3}

5-HTT-like immunoreactivity in lung sections from control subjects and patients with $\mathrm{PPH}$. (a) A lung section from a control subject with a weak to moderate 5-HTT-like immunoreactivity in pulmonary arterial endothelial cells and strong immunoreactivity in SMCs. (b-d) Lung sections from patients with PPH: 5-HTT-like immunoreactivity is much stronger, especially in the medial layer of pulmonary arteries with marked muscular hypertrophy (b). No 5-HTT immunostaining is detected in intimal fibrosis (c). In lesions with onion-bulb arrangement, 5-HTT-like immunoreactivity is prominent at sites of intense PA-SMC proliferation (d). (e) No immunoreactivity is detected in a section incubated with secondary $A b$, but no primary $A b$. Scale bar: $100 \mu \mathrm{m}$ in $\mathbf{a}, \mathbf{b}, \mathbf{c}$, and $\mathbf{e} ; 200 \mu \mathrm{m}$ in $\mathbf{d}$.

increase in the specific binding of $\left[{ }^{3} \mathrm{H}\right]$ citalopram was noted in patients with $\mathrm{PPH}$, suggesting that the higher 5-HT uptake resulted from an elevation in the 5-HTT protein level within platelets (Figure 1).

Expression and localization of 5-HTT in lungs from patients with PPH. Using competitive RT-PCR, we found that 5-HTT mRNA levels in lung tissues were approximately twice as high in patients with PPH as in controls (Figure 2). In the controls, immunohistochemical analysis revealed preferential localization of 5-HTT in the media of pulmonary arteries and weaker staining in the endothelium. In comparison, 5-HTT-like immunoreactivity was much stronger in lung specimens from patients with PPH, especially in the medial layer of pulmonary arteries with marked muscular hypertrophy. Immunostaining was more marked in those areas with more severe medial hypertrophy, as well as in intimal fibrosis lesions with an onion-bulb arrangement (Figure 3). No staining was seen in plexiform lesions.

Expression of 5-HTT in cultured PA-SMCs from patients with $P P H .\left[{ }^{3} \mathrm{H}\right] 5-\mathrm{HT}$ uptake in quiescently cultured PA-SMCs was markedly increased in patients with $\mathrm{PPH}$ as compared with controls (Figure 4). In a given individual, the level of $\left[{ }^{3} \mathrm{H}\right] 5-\mathrm{HT}$ uptake did not vary after three passages, compared with one passage, and remained stable although the cells were collected from a tissue explant that had been transferred several times. As noted above for platelets, fluoxetine caused concentration-dependent inhibition of $\left[{ }^{3} \mathrm{H}\right] 5-\mathrm{HT}$ uptake in PA-SMCs, with similar $\mathrm{IC}_{50}$ values in patients and controls (Figure 4). At the highest concentration of fluoxetine tested $\left(10^{-5} \mathrm{~mol} / \mathrm{l}\right)$, residual $\left[{ }^{3} \mathrm{H}\right] 5-\mathrm{HT}$ accumulation was very low and was similar in the two groups. In addition to $\left[{ }^{3} \mathrm{H}\right] 5-\mathrm{HT}$ uptake, the levels of both 5-HTT mRNA (Figure 5) and 5-HTT protein (estimated by Western blot analysis, Figure 6) in PA-SMCs were markedly higher in patients with $\mathrm{PPH}$ than in controls. To determine whether PA-SMCs had similar or distinct phenotypes in patients versus controls, we examined the immunohistochemical characteristics of the cells. Immunofluorescence showed that PA-SMCs from patients and controls produced similar levels of positive staining with Ab's against smooth muscle cell $\alpha$-actin, desmin, and vinculin (not shown).

Hyperplasia of cultured PA-SMCs from patients with PPH and the relation with 5-HTT expression. In cells cultured in $0.2 \%$ serum, 5 -HT produced a concentration-dependent increase in $\left[{ }^{3} \mathrm{H}\right]$ thymidine incorporation that was twice as high in PA-SMCs from patients than from controls (Figure 7). Pretreatment of the cells with fluoxetine $\left(10^{-5} \mathrm{~mol} / \mathrm{l}\right)$ or citalopram $\left(10^{-5} \mathrm{~mol} / \mathrm{l}\right)$, two 5 -HTT inhibitors (17), completely abolished the 5-HT-induced increase in $\left[{ }^{3} \mathrm{H}\right]$ thymidine incorporation, causing DNA synthesis to return to a similar basal level in PA-SMCs from patients and controls. In contrast, the mitogenic response to 5-HT was not affected by incubation of the cells with ketanserin and GR127935, which are 5- $\mathrm{HT}_{2 \mathrm{~A}}$ and $5-\mathrm{HT}_{1 \mathrm{~B} / 1 \mathrm{D}}$ receptor antagonists, respectively (18). When cultured in the presence of 2 or $5 \%$ serum, PASMCs from patients with $\mathrm{PPH}$ showed a higher growth rate than PA-SMCs from controls (Figure 8), but the difference in $\left[{ }^{3} \mathrm{H}\right]$ thymidine incorporation was abolished in the presence of fluoxetine (Figure 8). Serotonin concentration was $7 \mu \mathrm{M}$ in the serum used in this study. In contrast to the mitogenic response to $5-\mathrm{HT}$, the responses to EGF, FGFa, TGF- $\beta$, and PDGF did not differ between patients with PPH and controls (Figure 9).

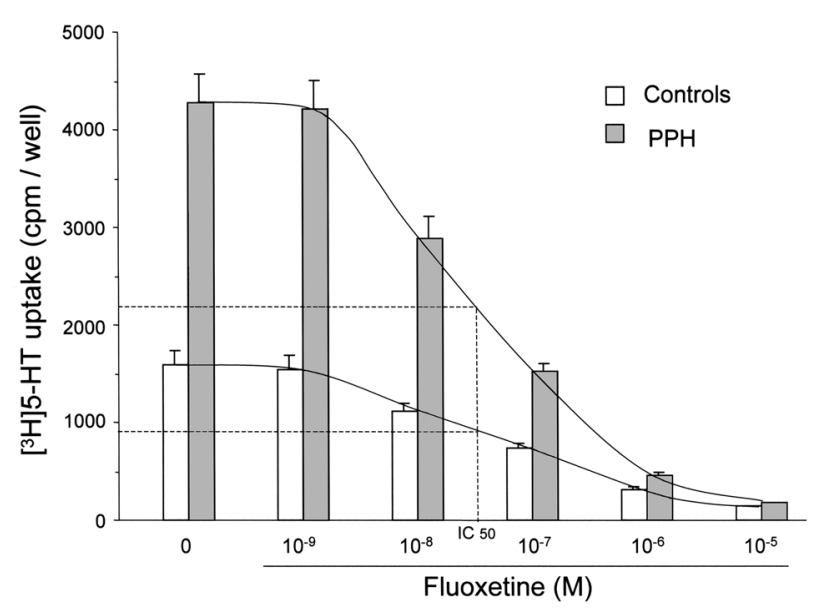

\section{Figure 4}

$\left[{ }^{3} \mathrm{H}\right] 5-\mathrm{HT}$ uptake in PA-SMCs from patients with $\mathrm{PPH}(n=8)$ and from controls $(n=8)$. Effects of increasing concentrations of fluoxetine $\left(10^{-9} \mathrm{~mol} / \mathrm{l}\right.$ to $\left.10^{5} \mathrm{~mol} / \mathrm{l}\right) . P<0.01$ for comparison between patients and controls (ANOVA). The dotted lines indicate the graphical determination of the $I C_{50}$ values of fluoxetine in the two groups $\left(2.7 \times 10^{-8} \mathrm{~mol} / \mathrm{l}\right.$ and $2.3 \times 10^{-8} \mathrm{~mol} / \mathrm{l}$ in patients with $\mathrm{PPH}$ and in controls, respectively). 


\section{Figure 5}

5-HTT mRNA levels in PA-SMCs from patients with $\mathrm{PPH}(n=8)$ and from controls $(n=9)$. Values are the means \pm SEM. ${ }^{*} P<0.01$ as compared with controls.

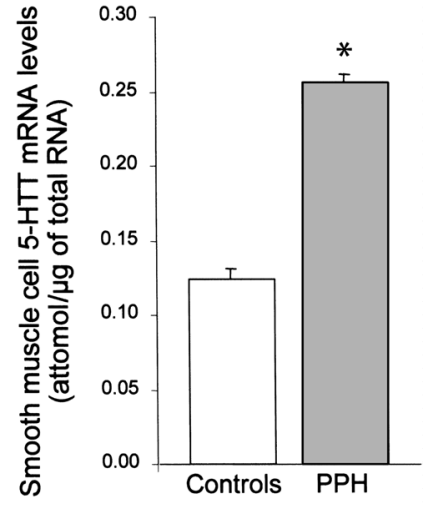

However, when combined to PDGF, 5-HT still induced more growth stimulation of cells from patients than of cells from controls. This difference between cells from patients and controls was completely abolished by fluoxetine (Figure 9). Fluoxetine did not alter cell proliferation caused by PDGF alone (data not shown).

Influence of the 5-HTT gene polymorphism on 5-HTT expression and PA-SMC proliferation. To evaluate the influence of 5-HTT gene polymorphism on serotonin uptake and serotonin-induced PA-SMC proliferation, PA-SMCs from three subgroups of controls with the LL, LS, and SS promoter variants were selected. $\left[{ }^{3} \mathrm{H}\right] 5-\mathrm{HT}$ uptake was significantly more marked in cells homozygous for the $L$ variant than in cells having one or two copies of the $S$ variant. In addition, cells with the LS promoter variant took up more $\left[{ }^{3} \mathrm{H}\right] 5-\mathrm{HT}$ than cells homozygous for the $\mathrm{S}$ variant (Figure 10). On the other hand, measurement of $\left[{ }^{3} \mathrm{H}\right]$ thymidine incorporation allowed the demonstration that cells from individuals with the LL genotype also showed a stronger growth response to 5-HT than cells with either the LS or the SS promoter variant; in addition, 5-HT-induced proliferation was more marked with SMCs with the LS compared with the SS genotype (Figure 10).

Of the PA-SMCs from the eight patients with $\mathrm{PPH}$, six were LL and two were LS. A close correlation was found between $\left[{ }^{3} \mathrm{H}\right] 5$-HT uptake and $\left[{ }^{3} \mathrm{H}\right]$ thymidine incorporation in cells from the controls or from the overall population of patients and controls (Figure 11). We were unable to compare SMC proliferation across 5-HTT polymorphisms in the patients with $\mathrm{PPH}$ because of the marked predominance of LL subjects and absence of SS subjects in this group. Cells from PPH patients with either the LL or LS promoter variant had greater rates of $\left[{ }^{3} \mathrm{H}\right] 5-\mathrm{HT}$ uptake and stronger growth responses to 5-HT than their respective samegenotype controls (Figure 11).

Distribution of 5-HTT genotypes in patients with PPH versus controls. The distributions of the 5-HTT genotypes in 89 patients with PPH and 84 controls were evaluated (Table 1). Patients and controls did not differ with respect to age and body mass indices, and all subjects were white. The 5-HTT genotypes in cases and controls were distributed according to the Hardy-Weinberg equilibrium. We found the genotype characterized by two long alleles in $65 \%$ of the patients with $\mathrm{PPH}$ and only $27 \%$ of the controls $(P<0.001)$. In the subgroup of 20 dexfenfluramine users (defined as patients treated with the drug for longer than 1 month), the distribution of 5-HTT gene polymorphisms was similar to that in the $69 \mathrm{PPH}$ patients who had never used the drug. The LL genotype was found in $70 \%$ of dexfenfluramine users and $64 \%$ of nonusers (NS).

\section{Discussion}

The present results show that PA-SMCs from patients with PPH grow faster than PA-SMCs from controls when stimulated by serotonin or serum and that these effects are due to increased expression of the serotonin transporter, which mediates internalization of indoleamine. Because the L allelic variant of the 5-HTT gene promoter, associated with 5-HTT overexpression, was more common in patients with PPH than in controls, the results suggest that 5-HTT gene polymorphism may confer susceptibility to PPH.

A primary objective of the present study was to assess the role of 5-HTT in mediating the mitogenic and comitogenic effects of 5-HT in human PA-SMCs from patients with $\mathrm{PPH}$ versus controls. We found that 5 -HT was a potent inducer of human PA-SMC proliferation and that its effect was dose-dependently inhibited by the highly selective 5-HT transport inhibitors fluoxetine and citalopram but not by the 5-HT receptor antagonists ketanserin and GR127935. The comitogenic activity of 5-HT measured in the presence of PDGF was also inhibited by fluoxetine, but this drug had no effect on cell proliferation due to PDGF alone.
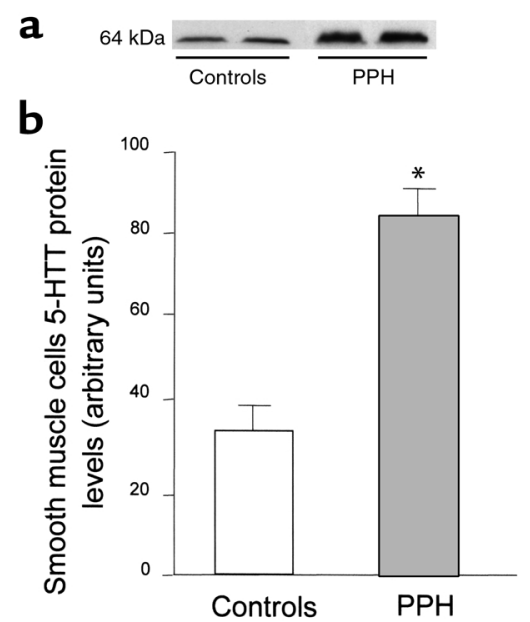

\section{Figure 6}

Western blot analysis of 5-HTT protein in PA-SMCs from patients with $\mathrm{PPH}$ and from controls. (a) 5-HTT immunoreactivity detected in cells from two controls (lanes 1 and 2) and from two patients (lanes 3 and 4). The specific Ab's recognize a protein with an apparent molecular weight of $64 \mathrm{kDa}$. (b) Quantification of the 5-HTT signal in each group. Each bar is the mean \pm SEM of OD (arbitrary units) at the $64-\mathrm{kDa}$ signal in cells from six patients and six controls. ${ }^{*} P<0.05$ as compared with $5-\mathrm{HTT}$ protein levels in cultured PA-SMCs from controls. 


\section{Figure 7}

$\left[{ }^{3} \mathrm{H}\right]$ thymidine incorporation in cultured PA-SMCs from patients with PPH (filled bars) and from controls (open bars). The cells were incubated with increasing concentrations of 5 -HT $\left(10^{-8}\right.$ to $\left.10^{-6} \mathrm{~mol} / \mathrm{l}\right)$ in the presence of $0.2 \%$ FCS. The response was also measured in the presence of ketanserin (Ket; $10^{-6} \mathrm{~mol} / \mathrm{l}$ ), GR 127935 ( $\left.10^{-6} \mathrm{~mol} / \mathrm{l}\right)$, fluoxetine (Fluox; $10^{-5} \mathrm{~mol} / \mathrm{I}$ ), or citalopram (Cita; $10^{-5} \mathrm{~mol} / \mathrm{l}$ ). Each of these compounds was added $20 \mathrm{~min}$ utes before $5-\mathrm{HT}$. Values are the means \pm SEMs of data determined in eight patients and eight controls. ${ }^{*} P<0.05,{ }^{*} P<0.01$ as compared with values for cells from controls.

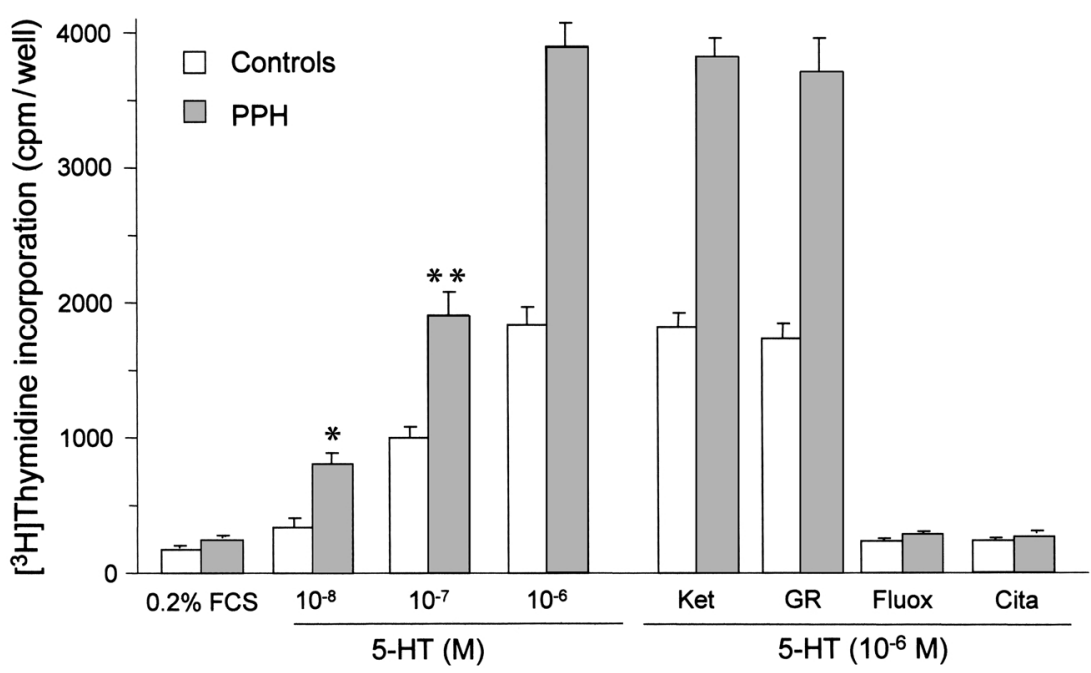

explant transfers. It has been suggested that the arterial media may contain functionally distinct PA-SMC populations with different migratory and proliferative capabilities, notably in response to PDGF and FGF, as well as different cell levels of contractile and cytoskeletal proteins (20). In our study, cells were isolated in the absence of a 5-HTT inhibitor, which may have promoted preferential growth of SMCs with increased 5-HTT activity. However, PA-SMCs from both patients and controls exhibited similar growth responses to PDGF, EGF, FGFa, and TGF- $\beta$ and similar cell levels of $\alpha$-SM-actin, desmin, and vinculin. These observations are strong evidence against the presence of distinct PA-SMC populations or PA-SMC phenotypes in patients versus controls. Interestingly, the increase in 5-HTT protein expression in patients with PPH was not restricted to the lung but was also found in platelets.

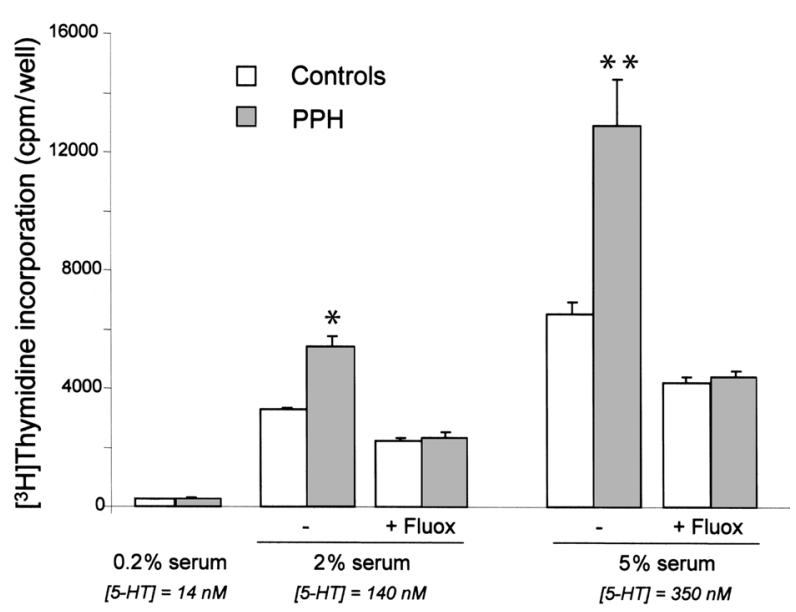

Figure 8

$\left[{ }^{3} \mathrm{H}\right]$ thymidine incorporation in PA-SMCs from patients with $\mathrm{PPH}$ (filled bars) and from controls (open bars) after exposure to various concentrations of FCS. The response was also measured in the presence of fluoxetine $\left(10^{-5} \mathrm{~mol} / \mathrm{l}\right)$. Values are the means \pm SEM of data obtained in eight patients and eight controls. ${ }^{*} P<0.05$ and ** $P<0.01$ as compared with values for cells from controls. 


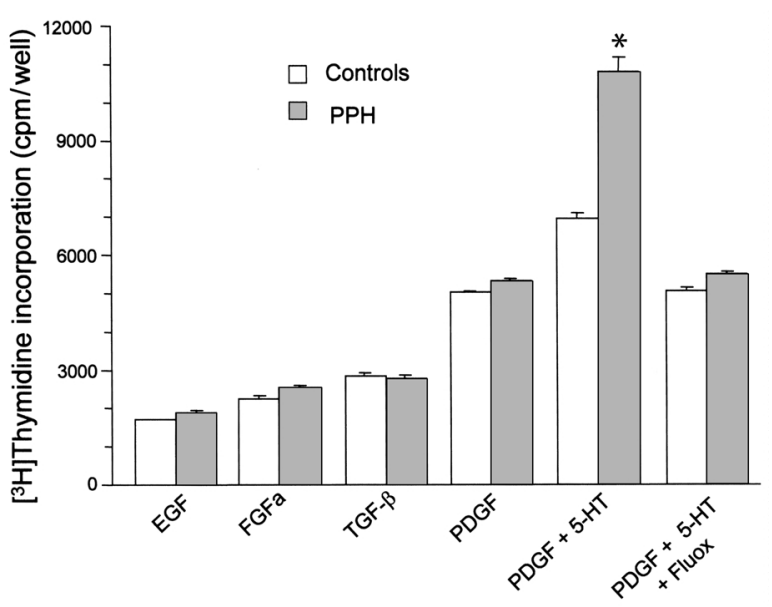

Figure 9

$\left[{ }^{3} \mathrm{H}\right]$ thymidine incorporation in cultured PA-SMCs from patients with $\mathrm{PPH}$ (filled bars) and from controls (open bars). The cells were incubated with EGF, FGFa, TGF- $\beta$, PDGF $(10 \mathrm{ng} / \mathrm{ml})$, or PDGF associated with $5-\mathrm{HT}\left(10^{-6} \mathrm{~mol} / \mathrm{l}\right)$. The response to PDGF + 5-HT was also measured in the presence of fluoxetine $\left(10^{-5} \mathrm{~mol} / \mathrm{l}\right)$. Values are the means \pm SEMs of data obtained in eight patients and eight controls. ${ }^{*} P<0.05$ as compared with the respective value for cells from controls.

An increase in platelet 5-HTT protein indicates increased 5-HTT synthesis by platelet precursor cells and consequently any indirect effects of altered pulmonary hemodynamics on 5-HTT synthesis are unlikely. The observation that cultured PA-SMCs from patients with PPH retain their ability to overexpress 5-HTT in the absence of additional stimuli, together with the increased 5-HTT activity in the platelets of patients with $\mathrm{PPH}$, strongly support a genetic basis for 5-HTT overexpression in PPH.

Compelling evidence has been obtained that 5-HTT expression is genetically controlled and that a polymorphism in the promoter region of the human 5-HTT gene affects transcriptional activity $(12,21)$. Studies of human lymphoblasts showed that the long $(\mathrm{L})$ promoter variant was associated with increased 5-HTT expression as compared with the short $(\mathrm{S})$ variant and resulted in increased 5-HTT uptake (8). In our studies of PA-SMCs from controls, we found that cells with the LL genotype took up more 5-HT than cells with the SS or LS genotype. Accordingly, the growth-stimulating effects of 5-HT or serum were more marked in LL cells than in LS or SS cells, indicating that the capability of PA-SMCs to proliferate in response to serotonin or serum was directly linked to the functional polymorphism of the 5-HTT gene promoter. These results differ to some extent from those reported by Lesch et al. (12), who found that the $S$ variant appeared to exert a dominant influence, since homozygous SS cells and heterozygous LS cells showed identical 5-HTT expression and 5-HT uptake. In contrast, in our studies conducted in PA-SMCs, 5-HTT activity was higher in LS than in SS cells, suggesting a more subtle effect of 5-HTT gene polymorphism on 5-HTT activity than that inferred from studies of lymphoblasts. We were unable to look for differences in SMC proliferation across 5-HTT gene poly- morphisms because of the marked predominance of LL subjects in this group of patients with PPH. Evaluation of the proliferative response of SS cells would be of interest because these cells may show either no response or intermediate response enhancement as compared with cells from controls.

Interestingly, we found that the $\mathrm{L}$ variant of the 5-HTT gene polymorphism associated with 5-HTT overexpression was considerably more common in patients with PPH than in controls, implying that this allele may confer susceptibility to PPH. It is unlikely that population heterogeneity could explain our results: in each population, the cases and controls were carefully selected to minimize ethnic heterogeneity; all our study subjects were white. Moreover, the distribution in the control group was similar to that recently reported by Gustavsson et al. in a general population of white individuals (22). Therefore, 5-HTT gene polymorphism appears to be much more strongly associated with PPH than with mood disorders. 5-HTT is the main target of many antidepressants, and considerable attention has been directed to the possible role for 5-HTT in the pathophysiology of depressive disorders (17). Linkage studies of 5-HTT gene polymorphisms have shown relations between the $S$ allelic variant of the 5 -HTT gene promoter and anxiety symptoms in normal individuals (12), suicidal behavior (23), and severe alcoholism (24). A preliminary report of a case-control study performed in Europe indicated lower levels of psychoanaleptic drug use in $\mathrm{PPH}$ patients than in controls (25) and suggested that the use of psychoanaleptic drugs lowered the odds ratio for developing PPH. An alternative hypothesis is that patients with PPH, who are less likely to carry the $S$ allelic variant than the population at large, may be less prone to anxiety-related traits than subjects without PPH.
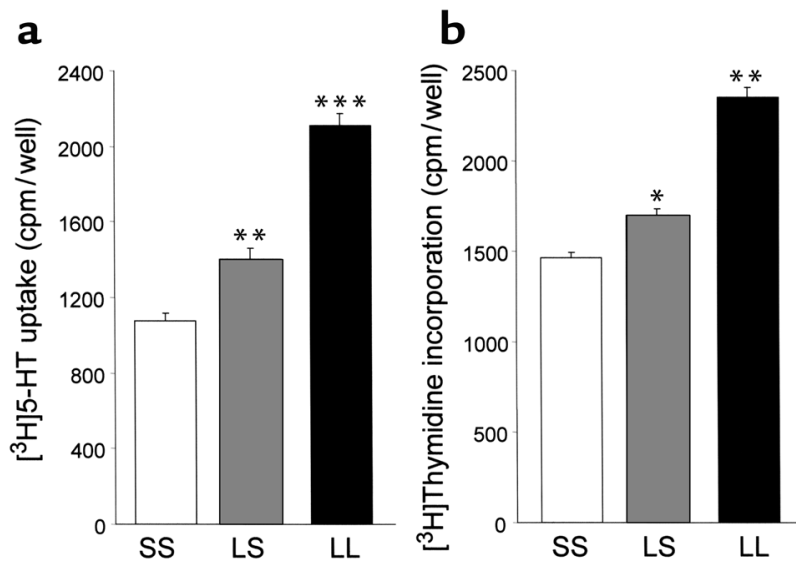

\section{Figure 10}

$\left[{ }^{3} \mathrm{H}\right] 5-\mathrm{HT}$ uptake (a) and $\left[{ }^{3} \mathrm{H}\right]$ thymidine incorporation (b) in response to $5-\mathrm{HT}\left(10^{-6} \mathrm{~mol} / \mathrm{l}\right)$ in SMCs from controls with the SS, LS, or LL genotype. Each bar is the mean \pm SEM of data obtained in six individuals in each group. ${ }^{*} P<0.05,{ }^{*} P<0.01,{ }^{*}{ }^{*} P<0.001$ as compared with respective values for the SS genotype. $\left[{ }^{3} \mathrm{H}\right] 5-\mathrm{HT}$ uptake and $\left[{ }^{3} \mathrm{H}\right]$ thymidine incorporation were also greater in $\mathrm{LL}$ cells than in LS cells $(P<0.01)$. 


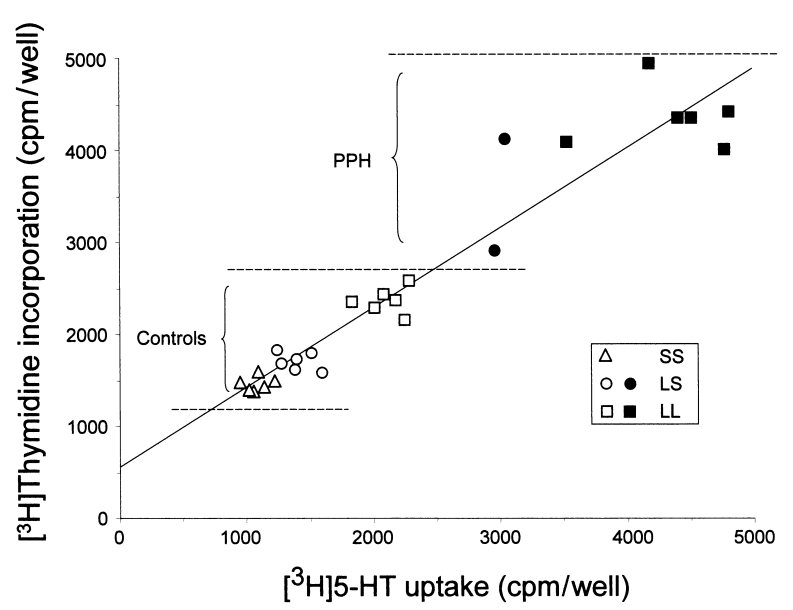

Figure 11

Correlation between $\left[{ }^{3} \mathrm{H}\right]$ thymidine incorporation and $\left[{ }^{3} \mathrm{H}\right] 5-\mathrm{HT}$ uptake in PA-SMCs from patients with PPH ( $n=7$; filled symbols) and from controls ( $n=18$; open symbols) with the SS (triangles), LS (circles), or LL (squares) genotype. A positive correlation ( $r=0.95$, $P<0.001)$ was found between the two series of values in both the patients and the controls.

Although the present results demonstrate that the long allele of the 5-HTT gene promoter is associated with increased serotonin uptake in PA-SMCs and is strongly associated with $\mathrm{PPH}$, they do not fully explain the increased 5-HTT expression in patients with PPH: 5-HTT expression in PA-SMCs from patients with PPH was higher than in same-genotype cells from controls. Thus, concomitant factors are probably needed to produce 5-HTT overexpression in PPH. Whether this overexpression results from an alteration in the 5 -HTT gene itself or from alterations in other factors involved in regulating 5-HTT gene expression remains to be determined. In recent studies, mutations in the coding sequence of the BMPR2 gene were found in more than $50 \%$ of patients with familial PPH and in at least $25 \%$ of patients with sporadic PPH $(2,3)$. The functional impact of BMPR2 mutations on the pathogenesis of pulmonary vascular remodeling is under investigation. An attractive hypothesis is that BMPR2 protein dysfunction may impair the control of cellular proliferation or gene transcription. If this is the case, increased 5-HTT gene expression in some individuals may result from abnormal signaling through the mutated BMPR2 protein. Alternatively, PPH may result from several genetic predisposing factors, and altered genetic control of BMPR2 and 5-HTT may play independent roles in the pathogenesis of the vascular lesion characteristic of $\mathrm{PPH}$.

Our finding that 5-HTT gene expression is a key determinant of SMC proliferation in patients with $\mathrm{PPH}$ supports novel therapeutic approaches. Given that selective 5-HTT inhibitors reduce SMC proliferation, they may protect from the vascular lesions associated with PPH. In keeping with this hypothesis, we recently found that citalopram treatment or 5-HTT gene disruption in mice diminished the pulmonary vascular remodeling induced by chronic hypoxia exposure (9).
The evidence from this study that 5-HTT polymorphism may confer susceptibility to PPH suggests a mechanism by which appetite suppressants may increase the risk of PPH in humans. Epidemiological studies have established that fenfluramine, dexfenfluramine, and aminorex, but not other appetite suppressants, increase the risk of PPH $(5,26)$. A genetic predisposition has been postulated to explain why PPH develops in only a minority of the individuals who use these drugs. Fenfluramine-like medications may elevate circulating 5-HT levels by releasing platelet 5-HT, which in turn may increase pulmonary artery pressure and PA-SMC growth, thereby producing PPH in susceptible individuals (7). More recently, it was shown that the above-mentioned appetite suppressants acted as 5-HTT substrates and produced the same effect as 5-HT (27). Another mechanism by which these drugs may promote pulmonary vascular remodeling is stimulation of 5-HTT expression. We found recently that discontinuation of chronic dexfenfluramine treatment in rats was followed by increased lung 5-HTT expression, which promoted the development of hypoxic PH (28). Individuals with a high basal serotonin uptake related to presence of the long 5-HTT gene promoter variant may be particularly susceptible to one or more of these potential mechanisms of appetite suppressant-related PPH. Interestingly, the distribution of 5-HTT gene polymorphisms was similar in the PPH patients who had and had not received dexfenfluramine treatment. This observation is consistent with the hypothesis that the long 5-HTT gene promoter variant may confer susceptibility to PPH associated with dexfenfluramine use. Confirmation of this hypothesis, however, would require further studies of subjects who took appetite suppressants but did not develop PPH.

Whether 5-HTT gene overexpression is associated with other forms of secondary PH deserves discussion. Most cases of PH occur in association with diseases such as collagen vascular disease, portal hypertension, HIV infection, congenital systemic-to-pulmonary shunt, respiratory disorders, or chronic thromboembolic lung disease (1). In most of these conditions in adults, as well as in persistent $\mathrm{PH}$ in neonates, a genetic predisposition has been suggested. Moreover, a role for 5-HTT in experimental hypoxic PH is now clearly established, and we have also reported increased 5-HTT

\section{Table 1}

Genotypic distribution of serotonin transporter gene polymorphism in the promoter region in patients with $\mathrm{PPH}$ and in controls

\begin{tabular}{llccc}
\hline \multirow{2}{*}{ Number of subjects } & \multicolumn{3}{c}{ Polymorphism in promoter region } \\
& & SS & LS & LL \\
& & $n(\%)$ & $n(\%)$ & $n(\%)$ \\
Normal controls & $84(100 \%)$ & $16(19 \%)$ & $45(54 \%)$ & $23(27 \%)$ \\
Patients with PPH & $89(100 \%)$ & $7(8 \%)$ & $24(27 \%)$ & $58(65 \%)$
\end{tabular}

$\mathrm{S}$, short variant of genotypic polymorphism. L, long variant of genotypic polymorphism. 
activity in platelets from patients with chronic hypoxemic lung disease (29). Thus, the associations linking 5-HTT overexpression to PH and 5-HTT gene polymorphism to susceptibility to $\mathrm{PH}$ probably exist in various types of $\mathrm{PH}$ in humans.

In conclusion, the present results support a crucial role of 5-HTT activity in the pathogenesis of pulmonary vascular remodeling and suggest that functional polymorphism of the 5-HTT gene promoter may confer susceptibility to PPH. Agents capable of selectively inhibiting 5-HTT-mediated PA-SMC proliferation deserve to be investigated as potential treatments for $\mathrm{PH}$.

\section{Acknowledgments}

This study was supported by grants from the INSERM, the Bristol-Myers Squibb Foundation (unrestricted biomedical research grant), the Fondation de France, the Association Française contre les Myopathies and Université Paris-Sud.

1. Rubin, L.J. 1997. Primary pulmonary hypertension. N. Engl. J. Med. 336:111-117.

2. Deng, Z., et al. 2000. Familial primary pulmonary hypertension (gene PPH1) is caused by mutations of the bone morphogenetic protein receptor-II gene. Am. J. Hum. Genet. 67:737-744.

3. Lane, K.B., et al. 2000. Heterozygous germline mutations in BMPR2, encoding a TGF $\beta$ receptor, cause familial primary pulmonary hypertension. Nat. Genet. 26:81-84

4. Wagenvoort, C.A., and Wagenvoort, N. 1970. Primary pulmonary hypertension. A pathologic study of the lung vessels in 156 clinically diagnosed cases. Circulation. 42:1163-1171.

5. Abenhaim, L., et al. 1996. Appetite-suppressant drugs and the risk of primary pulmonary hypertension. N. Engl. J. Med. 335:609-616.

6. Eddahibi, S., et al. 1997. Treatment with 5-HT potentiates development of pulmonary hypertension in chronically hypoxic rats. Am.J. Physiol. 272:H1173-H1181.

7. Eddahibi, S., et al. 1999. Induction of serotonin transporter by hypoxia in pulmonary vascular smooth muscle cell. Relationship with the mitogenic action of serotonin. Circ. Res. 84:329-336.

8. Lee, S.L., Wang, W.W., Moore, B.J., and Fanburg, B.L. 1991. Dual effect of serotonin on growth of bovine pulmonary artery smooth muscle cells in culture. Circ. Res. 68:1362-1368.

9. Eddahibi, S., et al. 2000. Attenuated hypoxic pulmonary hypertension in mice lacking the 5-hydroxytryptamine transporter gene. J. Clin. Invest. 105:1555-1562.

10. Lesch, K.P., Wolozin, B.L., Murphy, D.L., and Riederer, P. 1993. Primary structure of the human platelet serotonin uptake site: identity with the brain serotonin transporter. J. Neurochem. 60:2319-2322.
11. Ramamoorthy, S., et al. 1993. Antidepressant- and cocaine-sensitive human serotonin transporter: molecular cloning, expression, and chromosomal localization. Proc. Natl. Acad. Sci. USA. 90:2542-2546.

12. Lesch, K.-P., et al. 1996. Association of anxiety-related traits with a polymorphism in the serotonin transporter gene regulatory region. Science. 274:1527-1531.

13. Heils, A., et al. 1996. Allelic variation of human serotonin transporter gene expression. J. Neurochem. 66:2621-2624.

14. Gustavsson, J.P., et al. 1999. No association between serotonin transporter gene polymorphisms and personality traits. Am. J. Med. Genet. 88:430-436.

15. Gorwood, P., Batel, P., Adès, J., Hamon, M., and Boni, C. 2000. Serotonin transporter gene polymorphisms, alcoholism, and suicidal behavior. Biol. Psychiatry. 48:259-264.

16. Hallikainen, T., et al. 1999. Association between low activity serotonin transporter genotype and early onset alcoholism with habitual impulsive violent behavior. Mol. Psychiatry. 4:385-388.

17. Louis, W.J. 1999. Primary pulmonary hypertension and anorectic drugs. N. Engl. J. Med. 340:482-483.

18. Gurtner, H.P., et al. 1968. Häufen sich die primär vasculären formen des chronischen cor pulmonale? Schweiz. Med. Wochenschr. 98:1579-1584.

19. Fishman, A.P. 1999. Aminorex to fen/phen: an epidemic foretold. Circulation. 99:156-161.

20. Rothman, R.B., Ayestas, M.A., Dersch, C.M., and Baumann, M.H. 1999. Aminorex, fenfluramine, and chlorphentermine are serotonin transporter substrates. Implications for primary pulmonary hypertension. Circulation. 100:869-875.

21. Eddahibi, S., et al. 2001. Dexfenfluramine-associated changes in 5-HT transporter expression and development of hypoxic pulmonary hypertension in rats. J. Pharmacol. Exp. Ther. 297:148-154.

22. Eddahibi, S., et al. 1999. Serotonin uptake and citalopram binding in platelets from patients with chronic pulmonary hypertension. Am. J. Respir. Crit. Care Med. 159:A165. (Abstr.)

23. Prina, R., Dolfini, E., Mennini, T., Palermo, A., and Libertti, A. 1981 Reduced serotonin uptake by spontaneously hypertensive rat platelets. Life Sci. 29:2375-2379.

24. Chomczynski, P., and Sacchi, N. 1987. Single step method of RNA isolation by guanidinium thiocyanate-phenol-chloroform extraction. Anal. Biochem. 162:156-159.

25. Seibert, P.D., and Larrick, J.W. 1992. Competitive PCR. Nature. 359:557-558.

26. Gérard, C., et al. 1996. Quantitative RT-PCR distribution of serotonin 5-HT6 receptor mRNA in the central nervous system of control or 5,7dihydroxytryptamine-treated rats. Synapse. 23:164-173.

27. Hoyer, D., et al. 1994. VII. International Union of Pharmacology classification of receptors for 5-hydroxytryptamine (serotonin). Pharmacol. Rev. 46:157-203.

28. Lee, S.-D., et al. 1998. Monoclonal endothelial cell proliferation is present in primary but not secondary pulmonary hypertension. J. Clin. Invest. 101:927-934.

29. Frid, M.G., Aldashev, A.A., Dempsey, E.C., and Stenmark, K.R. 1997. Smooth muscle cells isolated from discrete compartments of the mature vascular media exhibit unique phenotypes and distinct growth capabilities. Circ. Res. 81:940-952. 